\title{
RAPORT GENERALNY - TRANSFORMACJA SYSTEMÓW PODATKOWYCH W PAŃSTWACH EUROPY ŚRODKOWO-WSCHODNIEJ - 25 LAT DOŚWIADCZEŃ ORAZ WYZWANIA NA PRZYSZŁOŚĆ - CZ. II ${ }^{1}$
}

Streszczenie. Niniejszy raport generalny powstał jako rezultat międzynarodowej konferencji nt. The Transformation of Tax Systems in the CEE and BRICS Countries - 25 years of experience and future challenges zorganizowanej przez Centrum Dokumentacji i Studiów Podatkowych Uniwersytetu Łódzkiego we współpracy z Międzynarodowym Biurem Dokumentacji Podatkowej w Amsterdamie

* Prof. zw. dr hab. Włodzimierz Nykiel, dr h.c., Katedra Prawa Podatkowego, Wydział Prawa i Administracji, Uniwersytet Łódzki, Centrum Dokumentacji i Studiów Podatkowych Uniwersytetu Łódzkiego.

** Dr hab. Ziemowit Kukulski, prof. nadzw. UŁ, Katedra Prawa Podatkowego, Wydział Prawa i Administracji, Uniwersytet Łódzki, Centrum Dokumentacji i Studiów Podatkowych Uniwersytetu Łódzkiego.

${ }^{1}$ Niniejszy raport generalny powstał jako rezultat międzynarodowej konferencji nt. The Transformation of Tax Systems in the CEE and BRICS Countries - 25 years of experience and future challenges zorganizowanej przez Centrum Dokumentacji i Studiów Podatkowych Uniwersytetu Łódzkiego we współpracy z Międzynarodowym Biurem Dokumentacji Podatkowej w Amsterdamie (International Bureau of Fiscal Documentation (IBFD) in Amsterdam), Fundacją Centrum Dokumentacji i Studiów Podatkowych, Polskim Oddziałem Międzynarodowego Stowarzyszenia Podatkowego (Polish Branch of International Fiscal Association, IFA). Konferencja ta odbyła się w dniach 9-10 października 2015 r. na Wydziale Prawa i Administracji Uniwersytetu Łódzkiego. 
(International Bureau of Fiscal Documentation (IBFD) in Amsterdam), Fundacją Centrum Dokumentacji i Studiów Podatkowych, Polskim Oddziałem Międzynarodowego Stowarzyszenia Podatkowego (Polish Branch of International Fiscal Association, IFA). Konferencja ta odbyła się w dniach 9-10 października 2015 r. na Wydziale Prawa i Administracji Uniwersytetu Łódzkiego.

Raport dotyczy ogólnych i szczegółowych aspektów transformacji systemów podatkowych i polityki podatkowej w państwach Europy Środkowej i Wschodniej w latach 1990-2015 w różnych obszarach prawa podatkowego: materialnego, proceduralnego oraz międzynarodowego. W raporcie zidentyfikowano także przyszłe wyzwania stojące przez systemami podatkowymi państw Europy Środkowej i Wschodniej. Zidentyfikowanie doświadczeń państw Europy Środkowej i Wschodniej na polu transformacji ich systemów podatkowych oraz przyszłych wyzwań jest krokiem niezbędnym na drodze do tworzenia lepszej legislacji podatkowej, przystającej do potrzeb podatników i administracji podatkowej we współczesnym świecie. W raporcie omówiono m.in. zagadnienia związane z relacjami między prawem konstytucyjnym a prawem podatkowym, standardy legislacji podatkowej, standardy i koncepcje polityki podatkowej państw Europy Środkowej i Wschodniej, problematykę oporu podatkowego, znaczenie i konstrukcję poszczególnych podatków, podatkowe aspekty zachęt podatkowych dla działalności badawczej i rozwojowej i innych ulg podatkowych, a także rodzajów interpretacji przepisów prawa podatkowego, proceduralnych gwarancji ochrony praw podatników i ich skuteczności. Ponadto w raporcie przeanalizowano rolę i znaczenie jednostronnych, dwustronnych i wielostronnych środków zapobiegających podwójnemu opodatkowaniu, w tym wpływ Konwencji Modelowej OECD w sprawie podatku od dochodu i kapitału, Konwencji Modelowej ONZ w sprawie unikania podwójnego opodatkowania między państwami rozwiniętymi a rozwijającymi się oraz OECD/G20 Planu Działań BEPS.

Słowa kluczowe: transformacja, system podatkowy, państwa państwa Europy Środkowej i Wschodniej, polityka podatkowa

1. PraWNe ASPEKTY TRANSFORMACJI SYSTEMÓW PODATKOWYCH I POLITYKI PODATKOWEJ PAŃSTW EUROPY ŚRODKOWO-WSCHODNIEJ - ZAGADNIENIA OGÓLNE

\subsection{Początki transformacji systemów podatkowych w państwach Europy Środkowo-Wschodniej}

Sprawozdawcy krajowi z państw Europy Środkowo-Wschodniej i Rosji wskazali na różne wydarzenia, które zainicjowały procesy transformacji ich krajowych systemów podatkowych. Antykomunistyczny ruch społeczny „Solidarność” w roku 1980 w Polsce, ogłoszony w 1985 r. przez Gorbaczowa program głasnost (jawność) oraz pieriestrojka (przebudowa) stworzyły atmosferę dla społecznych, politycznych i gospodarczych przemian w krajach komunistycznych.

Przełom roku 1989 i 1990 przyniósł poważne zmiany w byłej Czechosłowacji, Polsce, Rumunii i na Węgrzech. Niektórzy sprawozdawcy krajowi z tych państw wskazali symboliczne daty początku procesów transformacji: 4 czerwca 1989 r. - pierwsze częściowo wolne wybory do Sejmu po 
II wojnie światowej (Polska), grudzień 1989 - rewolucja antykomunistyczna (Rumunia). Aksamitna Rewolucja roku 1989 oraz rozpad Czechosłowacji 1 stycznia 1993 r. - zostały uznane za początek transformacji zarówno w Republice Czeskiej, jak i na Słowacji.

W przypadku Serbii wskazanie momentu inicjującego proces transformacji okazało się trudnym zadaniem. Proces ten bowiem jest ściśle związany z dramatycznymi zmianami wynikającymi z gwałtownego procesu rozpadu Jugosławii. Serbscy sprawozdawcy krajowi wskazali dwa odrębne okresy serbskiej transformacji: 1) ostatnią dekadę XX w., w której Serbia uczestniczyła w wojnie z państwami byłej Jugosławii i Kosowem oraz 2) pierwsze 15 lat XXI w. po obaleniu rządu Slobodana Miloševića, kiedy Serbia dołączyła do głównego nurtu, którym podążały pozostałe państwa Europy Środkowo-Wschodniej.

Z kolei początek transformacji systemów podatkowych Rosji, Gruzji i Mołdawii jest ściśle związany z rozpadem ZSRR. Proces ten w przypadku Gruzji i Mołdawii określono jako bardzo dynamiczny, rewolucyjny nawet, czego przykładem może być Rewolucja Róż w Gruzji z 2003 r.

1.2. Główne cechy systemów podatkowych państw Europy Środkowo-Wschodniej

We wszystkich byłych państwach socjalistycznych systemy podatkowe istniejące przed transformacją istotnie różniły się od funkcjonujących w zachodnich demokracjach. Ich kształt podporządkowany był ogólnym zasadom gospodarki centralnie planowanej. Do ich najbardziej charakterystycznych cech zaliczyć można: dominującą rolę państwa oraz przedsiębiorstw państwowych, brak wolnorynkowych mechanizmów, bezpośrednią kontrolę państwa nad wszelkimi aspektami produkcji i dystrybucji dóbr.

We wszystkich krajach socjalistycznych podatki i cła stanowiły integralną część dochodów budżetu państwa. Opodatkowanie różniło się w zależności od sektora gospodarki. Na podstawie tego kryterium można było wyróżnić trzy rodzaje podatków: podatki nakładane na sektor gospodarki uspołecznionej, podatki nakładane na sektor gospodarki nieuspołecznionej oraz podatki od ludności. Podatki nakładane na sektor gospodarki uspołecznionej odgrywały wiodącą rolę w strukturze dochodów budżetu państwa, znaczenie pozostałych podatków było marginalne. 
1.3. Miejsce prawa podatkowego w systemie prawa na początku transformacji

W szyscy sprawozdawcy krajowi z państw Europy Środkowo-Wschodniej podkreślili, że na początku transformacji, prawo podatkowe stanowiło integralną część prawa finansów publicznych. Jednakże w niektórych państwach Europy Środkowej (Polska, Słowacja) z biegiem lat prawo podatkowe wyodrębniło się z prawa finansów publicznych i dziś stanowi samodzielną gałąź prawa. W raportach krajowych z tych państw wskazano szereg argumentów teoretycznych i praktycznych przemawiających za autonomicznym charakterem prawa podatkowego.

Jednakże, co warto podkreślić, nawet dziś nadal głoszone są poglądy uznające prawo podatkowe za część prawa finansów publicznych (np. Czechy, Rosja i Serbia). Niemniej jednak, czescy sprawozdawcy krajowi zdecydowanie opowiedzieli się za odrębnością prawa podatkowego jako samodzielnej gałęzi prawa. Podobne tendencje odnotowano także w Rumunii, Rosji i Serbii.

\subsection{Związki między prawem konstytucyjnym a prawem podatkowym}

Wzajemne relacje między prawem konstytucyjnym a prawem podatkowym uznane zostały za bardzo ścisłe.

Transformacja systemów podatkowych w państwach Europy Środkowo-Wschodniej i Rosji wymogła wprowadzenie istotnych zmian także w obszarze konstytucyjnych regulacji dotyczących podatków. We wszystkich państwach Europy Środkowo-Wschodniej oraz w Rosji przyjęto nowe konstytucje.

Zasada nullum tributum sine lege (zasada ustawowego charakteru podatku) została expressis verbis uregulowana w ustawach zasadniczych Polski, Rumunii, Serbii, Słowacji i Węgier. Przeciwnie, Konstytucja Republiki Czeskiej nie zawiera wprost żadnych odniesień do podatków. Niemniej jednak konstytucje wszystkich państw Europy Środkowo-Wschodniej, w tym Republiki Czeskiej, zawierają szereg innych postanowień o doniosłym znaczeniu w odniesieniu także do podatków (fundamentalne prawa i wolności). Ponadto Konstytucja Słowacji wprost zakazuje referendum w sprawach podatkowych. Konstytucje pozostałych państw regionu co do zasady nie wprowadzają takiego zakazu. 
1.5. Podział władztwa podatkowego i dochodów podatkowych pomiędzy państwo, samorząd terytorialny oraz podmioty federacji

Podatki występujące w państwach Europy Środkowo-Wschodniej można podzielić na: podatki stanowiące dochody budżetu państwa (podatki państwowe) oraz podatki stanowiące dochody jednostek samorządu terytorialnego (podatki lokalne, samorządowe). Podział ten rzadko znajduje swoje oparcie w normach rangi konstytucyjnej, z wyjątkiem Słowacji, jego podstaw prawnych należy poszukiwać raczej w aktach prawnych rangi ustawowej.

Żadne z państw Europy Środkowo-Wschodniej nie jest państwem federalnym. Fakt ten znajduje odzwierciedlenie w przyjętych rozwiązaniach w zakresie autonomii podatkowej jednostek samorządu terytorialnego. Co do zasady, gminy, które są podstawowymi jednostkami samorządu terytorialnego we wszystkich państwach Europy Środkowo-Wschodniej korzystają z ograniczonej autonomii podatkowej. Nie mają bowiem prawa nakładania podatków lokalnych, z wyjątkiem Słowacji oraz Węgier, gdzie od 2015 r. organy samorządu lokalnego mogą ustanowić podatki i opłaty lokalne od niektórych transakcji dokonywanych wyłącznie przez osoby fizyczne. Mogą one jednak autonomicznie wprowadzać niektóre opłaty lokalne (np. opłata od posiadania psów w Czechach i Polsce).

Jednostki samorządu terytorialnego w państwach środkowoeuropejskich są uprawnione do określania stawek podatkowych - w granicach wynikających z ustaw oraz do wprowadzania określonych zwolnień i ulg podatkowych. Pozostałe jednostki samorządu terytorialnego (np. regiony, powiaty czy województwa) nie mają wpływu na wysokość swoich dochodów typu podatkowego (Czechy, Polska).

\subsection{Standardy procesu legislacji podatkowej}

Z wyjątkiem Rumunii, gdzie rząd może skorzystać z uproszczonej lub pilnej procedury w odniesieniu do regulacji podatkowych, nie ma odrębnej procedury legislacyjnej w sprawach podatkowych w państwach Europy Środkowo-Wschodniej.

Sprawozdawcy krajowi z państw środkowoeuropejskich wskazali na: 1) brak stabilności i spójnej wizji systemu podatkowego, 2) wysoki stopień złożoności i skomplikowania przepisów podatkowych, 3) brak przejrzystości i przewidywalności regulacji prawa podatkowego, 4) brak niezależnego nierządowego komitetu roboczego zaangażowanego $\mathrm{w}$ procesy tworzenia 
prawa podatkowego reprezentującego interesy różnych środowisk (np. biznesu, doktryny prawa podatkowego), oraz 5) brak publicznej debaty (Serbia) oraz wiele innych kwestii. W konkluzji zdiagnozowano, chroniczne podważanie zasady pewności prawa podatkowego.

Ponadto sprawozdawczynie krajowe z Gruzji i Mołdawii jednogłośnie podkreśliły brak doświadczenia oraz silny wpływ bieżącej polityki oraz społecznych żądań na proces legislacji podatkowej w ich krajach. Ich zdaniem, proces tworzenia prawa podatkowego, przynajmniej w początkowej fazie transformacji, można określić jako chaotyczny.

1.7. Rola sądu konstytucyjnego lub innego organu odpowiedzialnego za kontrolę jakości legislacji podatkowej

W państwach Europy Środkowo-Wschodniej sąd konstytucyjny posiada kompetencje do badania zgodności z konstytucją ustaw i rozporządzeń wykonawczych lub ich poszczególnych przepisów i w razie ich sprzeczności z ustawą zasadniczą do pozbawiania ich mocy obowiązującej. Działalność sądów konstytucyjnych stale wzrasta we wszystkich państwach środkowo- i wschodnioeuropejskich z wyjątkiem Czech, gdzie jego aktywność została określona w raporcie krajowym jako „względnie bierna”. Sprawozdawcy krajowi z Europy Środkowo-Wschodniej podkreślili, że orzecznictwo sądów konstytucyjnych w ich krajach stabilizuje krajowe prawo podatkowe i wywiera znaczący wpływ na jego rozwój (poza Serbią, której system podatkowy zasadniczo cierpi z powodu braku orzecznictwa w sprawach podatkowych).

\subsection{Koncepcja i standardy krajowej polityki podatkowej}

Zaobserwowano, że w początkowym stadium transformacji polityka podatkowa w państwach Europy Środkowo-Wschodniej koncentrowała się głównie na szybkiej i wręcz szokowej absorpcji standardów, które od dziesięcioleci funkcjonowały w Europie Zachodniej. Ponadto dalsze stadia transformacji systemów podatkowych państw środkowoeuropejskich, które uzyskały członkostwo w Unii Europejskiej kształtowane były potrzebą harmonizacji ich wewnętrznych porządków prawnych z prawem unijnym. Podobne cele polityki podatkowej zaobserwowano współcześnie także w Gruzji i Mołdawii, a także w Serbii w związku z aspiracjami tych państw do członkostwa w UE. 
Z perspektywy polityki podatkowej transformacja systemów podatkowych państw środkowo i wschodnioeuropejskich, która miała miejsce w ciągu ostatnich 25 lat uznana została, z pewnymi zastrzeżeniami, za sukces. Co do zasady, systemy podatkowe państw Europy Środkowo-Wschodniej spełniają dziś międzynarodowe standardy. Jednakże polityka podatkowa tych państw nadal pozostaje daleka od ideału. Sprawozdawcy środkowo- i wschodnioeuropejscy podkreślili, że ich wewnętrzna polityka podatkowa zbytnio zależy od sytuacji politycznej i podlega ustawicznym zmianom podyktowanym często wzajemnie wykluczającymi się politycznymi i socjalnymi bieżącymi celami.

\subsection{Prawne instrumenty realizujące pozafiskalne funkcje podatków}

Sprawozdawcy krajowi z Europy Środkowo-Wschodniej stwierdzili, że ich krajowe systemy podatkowe w pierwszej kolejności służą realizacji funkcji fiskalnej podatków. Zarówno zakres, jak i formy pozafiskalnych funkcji podatków jest dyskusyjny i trudny do jednoznacznego określenia.

Niemniej jednak wskazano kilka instrumentów prawnych, których celem jest realizacja pozafiskalnych funkcji podatków. Należą do nich: 1) obniżenie stawki podatku dochodowego od osób prawnych (Mołdawia, Rumunia, Serbia oraz Węgry) w celu przyciągnięcia zagranicznych inwestorów, 2) ustanowienie ulg podatkowych - zwłaszcza w początkowym okresie transformacji (Polska, Rumunia), 3) wprowadzenie szeroko pojmowanych regulacji o charakterze prorodzinnym oraz 4) inne preferencyjne reżimy opodatkowania, np. specjalne strefy ekonomiczne w Polsce oraz strefy wolnocłowe w Serbii.

\subsection{Problematyka oporu podatkowego}

Opór podatkowy manifestuje się, co do zasady, w dwóch formach: unikania opodatkowania oraz uchylania się od opodatkowania. Według sprawozdawców krajowych z państw Europy Środkowo-Wschodniej opór podatkowy jest $\mathrm{w}$ ich krajach społecznie akceptowany, zaś podatki postrzegane są raczej w kategoriach „zła koniecznego" niż obywatelskiej powinności. Co więcej, sprawozdawcy krajowi z niektórych państw Europy Środkowej (Węgry) dobitnie podkreślili presję nadmiernego obciążenia podatkowego (27\% stawka podatku VAT). Nadmierne obciążenie podatkowe zostało negatywnie ocenione przez węgierskich sprawozdawców 
krajowych. Niemniej jednak sprawozdawca krajowy ze Słowacji odnotował pozytywną zmianę nastawienia społecznego do opodatkowania. Zmiana ta przejawia się m.in. zaobserwowanym obecnie wzrostem wpływów budżetowych z tytułu podatków w porównaniu z poprzednim okresem. Dowodzić to może zarówno rosnącej efektywności poboru podatków, jak i rosnącej dyscypliny wśród podatników.

1.11. Członkostwo w międzynarodowych organizacjach oraz jego wpływ na krajowe ustawodawstwo podatkowe

Czechy (1995), Polska (1996), Węgry (1996) oraz Słowacja (2000) są państwami członkowskimi OECD. Tak więc, wpływ rekomendacji OECD (m.in. Konwencji Modelowej OECD w sprawie podatku od dochodu i majątku, Wytycznych OECD w sprawie cen transferowych oraz Planu Działania BEPS) jest wyraźnie zauważalny w krajowym ustawodawstwie tych państw.

Członkostwo Czech, Polski, Rumunii, Słowacji i Węgier w Unii Europejskiej zostało uznane za jedno z najważniejszych wydarzeń kształtujących kierunek transformacji systemów podatkowych w tych państwach. Uzyskanie statusu państwa członkowskiego UE oznaczało dla tych państw przyjęcie acquis communautaire. System prawny Unii Europejskiej nie tylko obejmuje prawo pierwotne i prawo wtórne UE, ale także wypracowane przez Trybunał Sprawiedliwości Unii Europejskie zasady wykładni prawa podatkowego, prawa celnego oraz jego case law.

Także prawo krajowe Serbii - oficjalnego kandydata do Unii Europejskiej - stopniowo kształtowane jest pod wpływem prawa unijnego. Podobne tendencje zauważono także w Gruzji i Mołdawii, które niedawno (rok 2014) podpisały Traktaty Stowarzyszeniowe z Unią Europejską.

1.12. Wpływ kryzysu finansowego na wewnętrzną politykę podatkową

Kryzys finansowy roku 2008 miał zróżnicowany wpływ na gospodarkę państw Europy Środkowej i Wschodniej. W niektórych wymusił on wprowadzenie antykryzysowych mechanizmów, których skuteczność została różnie oceniona przez sprawozdawców krajowych.

Kryzys finansowy roku 2008 ciężko doświadczył Węgry. Wprowadzono tam szereg tzw. podatków antykryzysowych, niektóre z nich naruszyły zakaz retroakcji, w tym m.in. podatek od sektora finansowego 
(tzw. podatek bankowy) o stawce dziesięciokrotnie wyższej niż stawki podobnego podatku w innych krajach. Wszystkie podatki antykryzysowe obowiązują do dziś. Sprawozdawcy krajowi z Węgier zauważyli, że gabinet premiera Orbana działa w sposób, jak gdyby kryzys finansowy jeszcze się nie skończył. W ich ocenie nadszedł czas, by zastąpić podatkowe instrumenty bezpośredniego oddziaływania stabilną polityką finansową, fiskalną i legalną.

Polska poradziła sobie dobrze z kryzysem finansowym roku 2008. Publiczne media prezentowały obraz Polski jako „zielonej wyspy”. Tak więc podatkowe instrumenty bezpośredniego oddziaływania nie zostały wprowadzone. Niemniej jednak spadek dochodów budżetowych wymusił podwyższenie stawek podatku od towarów i usług.

W Słowacji w związku z kryzysem finansowym przygotowano szereg antykryzysowych dokumentów rządowych, jednakże nie wprowadzono żadnych bezpośrednich mechanizmów zapobiegania jego skutkom.

Także w Rumunii nie zdecydowano się na bezpośrednie antykryzysowe instrumenty podatkowe. Niemniej jednak Rumunia poszerzyła zakres składek na ubezpieczenie społeczne pobieranych od wszelkich dochodów osób fizycznych, a także obniżyła wysokość wynagrodzenia w sektorze publicznym o 25\%.

Podobnie w Serbii, kryzys finansowy 2008 r. wymusił podwyższenie stawek podatku od wartości dodanej (VAT), co zostało boleśnie odebrane przez serbskie społeczeństwo. Niemniej jednak nie zdecydowano się na wprowadzenie żadnych tzw. podatków antykryzysowych. Zamiast tego podjęto próbę obniżenia wynagrodzeń pracownikom sektora publicznego, która została zakwestionowana przez Serbski Sąd Konstytucyjny jako „ukryta” forma opodatkowania.

\section{MATERIALNE PRAWO PODATKOWE W OKRESIE TRANSFORMACJI} SYSTEMÓW PODATKOWYCH W PAŃSTWACH EURopy ŚrodKOWO-WSCHODNIEJ

2.1. Uwagi wprowadzające

W państwach Europy Środkowo-Wschodniej i w państwach BRICS skutkiem transformacji było zastąpienie większości istniejących podatków nowymi. Skala zmian była kolosalna. Wielu sprawozdawców krajowych z państw Europy Środkowo-Wschodniej podkreśliło, że przepisy materialnego prawa podatkowego nie spełniają warunku stabilności i pewności, co spotkało się z negatywną oceną z ich strony. 
2.1.1. Rola, znaczenie oraz konstrukcja podatków pośrednich

Podatek od wartości dodanej, VAT, który zastąpił jednofazowe lub wielofazowe podatki obrotowe, został wprowadzony w państwach Europy Środkowo-Wschodniej w latach 90. W Czechach, Polsce, Rumunii, Słowacji i na Węgrzech, VAT uległ harmonizacji z prawem unijnym. Mimo podobieństw konstrukcji, stawki podstawowe oraz stawki obniżone VAT różnią się w zależności od kraju wysokością i wahają się od: 20\% (stawka podstawowa) w Słowacji, 23\% w Polsce, 25\% w Rumunii do 27\% na Węgrzech. VAT zazwyczaj stanowi dochód budżetu państwa i jest administrowany przez państwową administrację podatkową. W przypadku VAT-u od importu, należy on do właściwości administracji celnej w Czechach oraz w Polsce.

Podobnie, konstrukcja podatku akcyzowego - w przypadku olejów mineralnych (benzyna), napojów alkoholowych, wyrobów tytoniowych oraz energii - uległa harmonizacji z prawem Unii Europejskiej w tych państwach regionu, które są członkami tej organizacji. W niektórych z nich, np. Rumunii, akcyzę określono jako jeden z bardziej drażliwych podatków w kontekście uchylania się od opodatkowania. Rumuńskie społeczeństwo odnosi się do akcyzy z niechęcią ze względu na wielowiekową tradycję wytwarzania napojów alkoholowych w gospodarstwach domowych.

Także w Gruzji, Mołdawii oraz Serbii VAT, podatek akcyzowy oraz cła stanowią najbardziej wydajne fiskalnie źródła dochodów budżetu państwa. Stawki podstawowe VAT w tych państwach mieszczą się w granicach od 18\% (Gruzja) do 20\% (Mołdawia i Serbia). Sprawozdawcy krajowi z Mołdawii zauważyli, że w związku z podpisanym przez Mołdowę z Unią Europejską Europejskiego Planu Działań w zakresie Sąsiedztwa (ang. European Neighborhood Action Plan), system VAT w tym kraju dotknięty został wieloma poważnymi zmianami (np. eliminacja zwolnień i ulg, podwyższenie progów kwotowych wymaganych dla rejestracji dla potrzeb VAT). W rezultacie zaobserwowano wzrost dochodów budżetowych z tytułu tego podatku.

2.1.2. Rola, znaczenie oraz konstrukcja podatków bezpośrednich

W państwach Europy Środkowo-Wschodniej w okresie poprzedzającym transformację istniało kilka podatków, które dziś określono by jako podatki bezpośrednie. Należały do nich m.in. podatki od płac i wynagrodzeń, bezpośredni podatek od jednostek gospodarki nieuspołecznionej, podatek wyrównawczy i inne. U progu transformacji zastąpiono je powszechnym podatkiem dochodowym od osób fizycznych oraz powszechnym podatkiem dochodowym od osób prawnych. 
Podatki bezpośrednie w państwach Europy Środkowo-Wschodniej nie stanowią głównego źródła dochodów budżetowych (z wyjątkiem Serbii). Niemniej jednak odgrywają one ważną rolę.

Co do zasady, stawka podatku dochodowego od osób prawnych jest stała. Jej wysokość waha się pomiędzy 10\% w Serbii do 22\% w Rumunii. W niektórych państwach Europy Środkowo-Wschodniej początkowo stawka podatku dochodowego od osób prawnych była stosunkowo wysoka, następnie ulegała stopniowemu obniżeniu przy jednoczesnej likwidacji większości zwolnień i ulg podatkowych.

W zdecydowanej większości państw regionu również stawka podatku dochodowego od osób fizycznych ma charakter stawki stałej (w Rumunii i na Węgrzech - jednakowoż stawki podatku dochodowego od osób fizycznych były początkowo progresywne). Progresywne stawki podatku dochodowego od osób fizycznych występują w Mołdawii, Polsce i Serbii. W Czechach podatek dochodowy od osób fizycznych miał początkowo charakter progresywny. Jednakże w 2008 r. progresję zastąpiono podatkiem liniowym o stawce $15 \%$, by następnie wprowadzić ją ponownie w 2013 r. w związku z ustanowieniem tzw. podatku solidarnościowego. Serbski podatek dochodowy od osób fizycznych ma charakter podatku cedularnego.

\subsubsection{Rola, znaczenie i konstrukcja podatków majątkowych}

Sprawozdawcy krajowi z państw Europy Środkowo-Wschodniej ocenili, że podatki majątkowe w ich krajach mają przede wszystkim znaczenie uzupełniające, a ich rola uległa całkowitej zmianie $\mathrm{w}$ trakcie procesu transformacji, gdyż stały się one źródłem dochodów samorządu terytorialnego.

Prawodawstwa państw Europy Środkowo-Wschodniej znają cały szereg podatków majątkowych. Zaliczają się do nich: podatek od nieruchomości, podatek od nabycia oraz zbycia nieruchomości, podatek od czynności cywilnoprawnych i inne. Ponadto w niektórych państwach regionu (Polska oraz Słowacja) funkcjonuje podatek rolny, podatek leśny (Polska) oraz podatek drogowy, podatek od pojazdów drogowych (Czechy, Słowacja), lub podatek od środków transportowych (Polska).

Niektórzy sprawozdawcy krajowi wskazali na malejące znaczenie podatku od spadków i darowizn w związku z następującymi zdarzeniami: 1) zniesienie tego podatku w Czechach oraz 2) wprowadzenie zwolnienia dla najbliższych krewnych (tzw. zerowa grupa podatkowa) w Polsce. 
2.2. Kwestie szczególne

2.2.1. Opodatkowanie działalności gospodarczej

Co do zasady, dochody z działalności gospodarczej w państwach Europy Środkowo-Wschodniej podlegają opodatkowaniu na zasadach uregulowanych odpowiednio w ustawach o podatku dochodowym od osób fizycznych i/lub o podatku dochodowym od osób prawnych. Sprawozdawcy krajowi z tych państw wskazali na kilka ważnych różnic. Na przykład, zgodnie z czeskim prawem podatkowym, podatek od dochodów z działalności gospodarczej ustalany jest na podstawie reguł rachunkowości, zaś w Polsce stosowane są odmienne (podatkowe) reguły ustalania wysokości dochodu $\mathrm{z}$ tego tytułu do opodatkowania. W niektórych państwach regionu występują szczególne reżimy opodatkowania dochodów z działalności gospodarczej. Przybierają one różne formy: 1) zredukowana lub zerowa stawka podatkowa znajdująca zastosowanie do określonych rodzajów działalności gospodarczej lub przedsiębiorców (fundusze inwestycyjne, ubezpieczyciele w Czechach), 2) zryczałtowane koszty uzyskania przychodów (Rumunia), 3) alternatywny minimalny podatek dochodowy od osób prawnych dla podatników przynoszących straty (Węgry), 4) uproszczone formy opodatkowania (Gruzja, Polska, Serbia oraz Węgry).

\subsubsection{Podatkowe aspekty badań naukowych i rozwoju nowoczesnych technologii}

Funkcjonowanie podatkowych uregulowań w odniesieniu do badań naukowych i rozwoju nowoczesnych technologii odnotowano w czeskim, polskim, rumuńskim, słowackim oraz węgierskim raporcie krajowym. Rozwiązania przyjęte w ustawodawstwach państw regionu różnią się od siebie. Przykładowo, czescy i słowaccy przedsiębiorcy inwestujących w badania naukowe i rozwój nowoczesnych technologii mogą skorzystać z tzw. „super” odliczenia wydatków poniesionych na wymienione wyżej cele. Polskie i rumuńskie prawo podatkowe przewiduje odliczenie wydatków z tego tytułu (bezpośrednio od przychodów lub w drodze amortyzacji) oraz tzw. ulgę na nowe technologie. Ponadto w Czechach istnieje możliwość odliczenia wydatków poniesionych przez podatnika na szkolenia zawodowe. Ustawodawca węgierski oferuje podatnikom podatku dochodowego od osób prawnych zwolnienie połowy kwoty należności licencyjnych otrzymywane w związku z udzieleniem licencji na użytkowanie lub prawo do użytkowania nowoczesnych technologii oraz odliczenie 100\% wydatków 
(kosztów bezpośrednich oraz kosztów usług) poniesionych na badania naukowe i nowoczesne technologie. Jedynie w Serbii brak jakichkolwiek uregulowań podatkowych w zakresie wydatków poniesionych na badania naukowe i rozwój nowoczesnych technologii.

\subsubsection{Zachęty podatkowe i ich skuteczność}

W trakcie transformacji państwa Europy Środkowo-Wschodniej wprowadziły cały wachlarz rozmaitych zachęt podatkowych. W początkowym stadium przemian zachęty te w pierwszej kolejności miały za zadanie przyciągnąć zagranicznych inwestorów oraz zmobilizować krajowych przedsiębiorców. Przybrały one zróżnicowane formy, m.in.: 1) wyłączeń spod opodatkowania dywidend oraz dochodów z przeniesienia własności określonego rodzaju składników majątkowych (Węgry), 2) zwolnień podmiotowych dla nowo utworzonych podatników podatku dochodowego od osób prawnych oraz podatników inwestujących w określone branże przemysłu lub w słabiej rozwiniętych (zaniedbanych) regionach kraju (Rumunia, Serbia), 3) negocjacji ulg inwestycyjnych dla zagranicznych inwestorów (obecnie w Czechach) oraz 4) kredytu podatkowego udzielanego podmiotom inwestującym w środki trwałe oraz tworzącym nowe miejsca pracy (Serbia) i wiele innych.

Skuteczność ww. zachęt podatkowych została różnie oceniona przez sprawozdawców krajowych. Niektórzy podkreślali brak specjalnych narzędzi polityki podatkowej ukierunkowanej na przyciąganie zagranicznych inwestorów, z wyjątkiem specjalnych stref ekonomicznych (Polska) lub specjalnych stref wolnocłowych (Serbia).

\subsubsection{Kwestia „przejrzystości” podatkowej spółek osobowych}

Systemy podatkowe Serbii, Słowacji i Węgier nie należą do „transparentnych” pod względem podatkowym. Rumuński system podatkowy określono jako „semitransparentny”, w znaczeniu porównywalnym do rozwiązań funkcjonujących we Francji w tym zakresie (fr. translucide). Przeciwnie, czeski i polski system podatkowy są co do zasady transparentne, z jednym wyjątkiem spółek komandytowo-akcyjnych (Polska), które uzyskały status podatnika podatku dochodowego od osób prawnych od 2014 r. Pozostałe spółki osobowe prawa handlowego nie są podatnikami tego podatku. Oznacza to, że dochody uzyskiwane z działalności tych spółek podlegają opodatkowaniu wyłącznie na poziomie ich wspólników, jako dochody z prowadzonej przez wspólników działalności gospodarczej. 
Zgodnie z brazylijskim prawem wewnętrznym, jednostki organizacyjne typu niekorporacyjnego, spółki ciche oraz określone typy funduszy inwestycyjnych mają status podatników podatku dochodowego od osób prawnych.

Spółki cywilne nie są znane rosyjskiemu systemowi prawa. W ich miejsce wprowadzono kilka nowych rodzajów form organizacyjno-prawnych, głównie po to by przyciągnąć zagranicznych inwestorów, zwanych spółkami gospodarczymi (ang. business partnerships). Mają one status podatnika podatku dochodowego od osób prawnych.

2.2.5. Eliminacja podwójnego opodatkowania w sensie ekonomicznym

W systemach podatkowych Czech, Polski, Rumunii, Słowacji i Węgier nie występują mechanizmy służące eliminacji podwójnego opodatkowania w sensie ekonomicznym, poza uregulowaniami implementującymi Dyrektywę Rady o wspólnym systemie opodatkowania wypłat zysków między spółkami dominującymi i zależnymi różnych państw członkowskich (zwolnienie kapitałowe, zwolnienie partycypacyjne). Poza uregulowaniami opartymi na omawianej dyrektywie, sprawozdawcy krajowi z Węgier zwrócili uwagę na fakt, iż wewnętrzne prawo podatkowe tego kraju nie przewiduje podatku u źródła od dywidend wypłacanych na rzecz spółek dominujących-rezydentów państw nienależących do Unii Europejskiej, w przypadku których polskie prawo podatkowe przyznaje tzw. pośredni kredyt podatkowy w odniesieniu do dywidend otrzymywanych przez spółki dominujące-rezydentów Polski od spółek zależnych-rezydentów państw nieczłonkowskich. Serbia przyznaje zwolnienie pełne dywidend otrzymanych przez krajowych korporacyjnych udziałowców oraz pośredni kredyt podatkowy od dywidend otrzymanych przez nich z zagranicy. Od 2012 r. serbskie prawo podatkowe nie przewiduje żadnych instrumentów eliminujących ekonomiczne podwójne opodatkowanie w przypadku udziałowców/akcjonariuszy będących osobami fizycznymi. Brak mechanizmów przeciwdziałających temu zjawisku odnotowano także w Gruzji i Mołdawii.

Dwustronne i wielostronne umowy podatkowe, co do zasady, nie dotyczą kwestii podwójnego ekonomicznego opodatkowania, poza uregulowaniami w zakresie korekty zysków przedsiębiorstw powiązanych, lecz podwójnego opodatkowania w sensie prawnym. Warto podkreślić, że państwa członkowskie Unii Europejskiej zawarły wielostronną umowę zwaną Konwencją Arbitrażową w sprawie eliminacji ekonomicznego podwójnego opodatkowania w przypadku korekty zysków przedsiębiorstw powiązanych. 
2.2.6. Znaczenie osobistej sytuacji podatnika (m.in. sytuacji rodzinnej)

We wszystkich państwach Europy Środkowo-Wschodniej uregulowania podatku dochodowego od osób fizycznych biorą pod uwagę osobistą sytuację podatnika, w tym jego status rodzinny. Prorodzinne ulgi podatkowe przybierają różną postać, w tym: 1) odliczeń określonych kwot od kwoty podatku lub podstawy opodatkowania, których wysokość zależy od liczby podsiadanych dzieci (Czechy, Polska, Słowacja, Węgry), 2) zwolnień w podatku od spadków i darowizn adresowanych do najbliższych krewnych (Polska, Rumunia, Węgry), 3) ulg w niektórych podatkach lokalnych związanych $\mathrm{z}$ wiekiem podatnika (Słowacja), oraz 4) łącznego opodatkowania małżonków (Polska). Jedynie w przypadku Serbii sprawozdawcy krajowi stwierdzili, że cedularny charakter podatku dochodowego od osób fizycznych wprowadzony w 2001 r. nie pozwala na wprowadzenie instrumentów podatkowych uwzględniających osobistą sytuację podatnika.

3. Procedury podatkowe W OKREsie PrZemian SystemóW PODATKOWYCH W PAŃSTWACH EUROPY ŚRODKOWO-WSCHODNIEJ

3.1. Wprowadzenie

3.1.1. Rola organu nadzorującego administrację podatkową

W państwach Europy Środkowo-Wschodniej stosowane są różne rozwiązania tej kwestii. W Polsce i na Węgrzech funkcja ta powierzona jest ministrowi finansów lub odpowiednio ministrowi gospodarki narodowej, którzy są de iure i de facto organami nadzorującymi administrację podatkową. Jednakże węgierska administracja podatkowa określona została jako relatywnie niezależna, gdyż przewodniczący organów administracji podatkowej powoływani i odwoływani są przez premiera.

W Czechach administracja podatkowa formalnie podporządkowana jest ministrowi finansów, aczkolwiek de facto od roku 2011 organem zarządzającym administracją podatkową jest Generalny Dyrektoriat Podatkowy. Podobny model nadzoru i kontroli wprowadzono w Słowacji. Rumuńscy sprawozdawcy krajowi wskazali, że administracja podatkowa w ich kraju jest de iure i de facto niezależna od ministra finansów publicznych. Minister finansów publicznych i administracja podatkowa są samodzielnie reprezentowani $w$ trakcie debat parlamentarnych nad zmianami prawa podatkowego i niejednokrotnie prezentują odmienne stanowiska. Także w Serbii Państwowa Administracja Podatkowa określona została jako 
autonomiczna administracja funkcjonująca w strukturze serbskiego ministerstwa finansów, nadzorowana przez dyrektora powoływanego przez serbski rząd na wniosek ministra finansów.

W Gruzji i Mołdawii podatki i cła należą do właściwości scentralizowanej administracji podatkowej: Służba Podatkowa (Gruzja) oraz Główny Inspektorat Państwowy (Mołdawia), które są jednostkami organizacyjnymi ministerstw finansów, dzielącymi się na kilka różnych departamentów.

W wielu państwach środkowo- i wschodnioeuropejskich ministrowie właściwi w sprawach finansów publicznych odpowiadają za strategię polityki podatkowej oraz pośrednio, jako członkowie rady ministrów, wyposażeni są w inicjatywę ustawodawczą w zakresie podatków, zaś w niektórych państwach regionu (Polska, Węgry) są uprawnieni do wydawania aktów wykonawczych do ustaw podatkowych (rozporządzeń, dekretów) w sprawach podatkowych. Serbscy sprawozdawcy krajowi podkreślili istnienie odrębnej jednostki w ramach Państwowej Administracji Podatkowej odpowiedzialnej wyłącznie za kształt polityki podatkowej państwa.

3.1.2. Struktura administracji podatkowej oraz jej techniczne zaplecze

Struktura administracji podatkowej jest ściśle powiązana z przyjętym modelem organizacji administracji publicznej. Wskazano różne podejście do ww. kwestii w państwach Europy Środkowo-Wschodniej oraz w państwach BRICS.

Pominąwszy szczegóły, należy wskazać na następujące kwestie: 1) istnienie odrębnej administracji podatkowej oraz administracji celnej w niektórych państwach Europy Środkowo-Wschodniej (Czechy, Polska i Słowacja), 2) decentralizacja administracji podatkowej i ustanowienie odrębnej administracji podatkowej na szczeblu lokalnym (Polska, Słowacja, Węgry); w niektórych państwach regionu odnotowano odwrotne koncepcje (Gruzja, Mołdowa), 3) dwuinstancyjna lub trójinstancyjna struktura organizacyjna administracji podatkowej.

Polska, Słowacja, Serbia i Węgry przyjęły dwuinstancyjny model postępowania podatkowego. Cechami tego modelu są: dewolutywność kompetencji oraz zawieszenie wykonalności decyzji podatkowej wydanej przez organ pierwszej instancji. Inną cechą tego modelu jest inkwizycyjny charakter postępowania podatkowego, który wynika $\mathrm{z}$ natury postępowań administracyjnych.

W Rumunii zakwestionowanie decyzji organu podatkowego wymaga podjęcia następujących dwóch kroków: 1) wstępnym i obowiązkowym 
pierwszym krokiem jest wszczęcie postępowania przed organem, który wydał zaskarżoną decyzję; postępowanie to wszczynane jest wyłącznie na wniosek podatnika, zaś jego celem jest autoweryfikacja decyzji podatkowej przez organ podatkowy. Sprawy wszczęte w tym stadium rozstrzygane są przez specjalną komórkę administracji podatkowej, która zazwyczaj podtrzymuje kwestionowaną decyzję podatkową. Krok drugi to zaskarżenie decyzji podatkowej wydanej w tym trybie do sądu administracyjnego.

Interesujące rozwiązania przyjęto w Gruzji, gdzie proces rozstrzygania sporów między podatnikami a administracją podatkową angażuje jednocześnie dwa niezależne od siebie mechanizmy: dwuinstancyjne postępowanie odwoławcze oraz postępowanie sądowe.

We wszystkich krajach Europy Środkowo-Wschodniej restrukturyzacja administracji podatkowej przebiegała stopniowo. Nowe rozwiązania i usprawnienia są nadal wprowadzane. Mają one na celu zwiększenie efektywności poboru podatku (np. Czechy).

Niektórzy sprawozdawcy krajowi z Europy Środkowo-Wschodniej podkreślili względnie dobrą, choć nadal daleką od ideału materialną bazę oraz techniczne wyposażenie ich krajowych administracji podatkowych (Czechy, Polska, Rumunia, Węgry).

\subsubsection{Rodzaje interpretacji podatkowych}

Prawo podatkowe państw Europy Środkowo-Wschodniej zna co najmniej dwa rodzaje interpretacji podatkowych: 1) interpretacje ogólne i indywidualne oraz 2) uprzednie porozumienia cenowe (Czechy, Polska, Rumunia, Słowacja i Węgry).

Interpretacje ogólne wydawane $\mathrm{z}$ urzędu przez Ministra Finansów i wiążące dla organów administracji podatkowej występują w Polsce i Słowacji. Ich celem jest zapewnienie jednolitości wykładni przepisów prawa podatkowego przez organy podatkowe. Podobnego rodzaju interpretacje wydawane są także w Rumunii, z tą różnicą, iż dotyczą one jedynie przypadków sprzecznej interpretacji przepisów prawa podatkowego.

Wiążące interpretacje w sprawach indywidualnych są wydawane w Czechach, Polsce, Rumunii, Słowacji i na Węgrzech przez organy podatkowe na wniosek podatnika. W przypadku przyszłych transakcji (zdarzeń prawno-podatkowych), interpretacje indywidualne w niektórych państwach regionu są wiążące dla organów podatkowych przez ściśle określony czas (trzy lata w Czechach, pięć lat na Węgrzech). Ponadto prawo węgierskie przewiduje możliwość wydawania „przedłużonych” interpretacji 
indywidualnych dla podatników podatku dochodowego od osób prawnych (wiążą one dłużej o kolejne dwa lata).

Proces wydawania interpretacji indywidualnych jest, co do zasady, scentralizowany: w rękach organów administracji podatkowej (Polska, gdzie interpretacje tego rodzaju są de facto wydawane przez wskazane organy administracji podatkowej działające w imieniu Ministra Finansów) lub w rękach specjalnego organu (np. Instytut Wiążących Interpretacji w Słowacji od 2014 r.).

W Polsce i na Węgrzech interpretacje indywidualne podlegają sądowej kontroli, natomiast w Czechach i Rumunii zaskarżenie takich interpretacji nie jest dozwolone. Sprawozdawcy krajowi z Czech i Węgier podkreślili wysoką opłatę pobieraną w związku z wniesieniem wniosku o udzielenie interpretacji indywidualnej, natomiast w Polsce opłata ta ma charakter symboliczny (ok. 10 euro).

Interpretacje indywidualne nie występują w Gruzji, Mołdawii i Serbii. W Serbii opinie (stanowisko) ministra finansów są uwzględniane w procesie wykładni przepisów prawa podatkowego. Od 2013 r. wykładnia przepisów prawa podatkowego zawarta w opiniach serbskiego ministra finansów jest wiążąca dla administracji podatkowej.

\subsubsection{Procesowe gwarancje praw podatnika i ich skuteczność}

Prawo proceduralne w państwach Europy Środkowo-Wschodniej zawiera szereg unormowań, które pełnią funkcję procesowych gwarancji praw podatnika. Do norm tych należy zaliczyć w pierwszej kolejności zwyczajne i nadzwyczajne środki zaskarżania decyzji podatkowych (np. odwołanie, wznowienie postępowania podatkowego). Ponadto należą do nich również zasady ogólne postępowania podatkowego, w tym zasada praworządności, zasada poufności, zasada czynnego udziału strony w postępowaniu podatkowym.

Interesujące rozwiązanie zostało wskazane przez sprawozdawczynię krajową z Gruzji, mianowicie funkcjonowanie osobistego doradcy podatnika, którym jest $\mathrm{z}$ reguły pracownik organu administracji podatkowej, do zadań którego należy udzielanie podatnikowi niezbędnej pomocy w zakresie jego praw i obowiązków.

W kwestii równowagi między prawami i obowiązkami podatników wielu środkowo- i wschodnioeuropejskich sprawozdawców krajowych podkreśliło nadrzędną, dominującą rolę organów podatkowych w toku postępowania podatkowego oraz jego inkwizycyjny charakter. Przytoczono 
także przykłady ewidentnego naruszenia prawa podatkowego przez organy podatkowe niektórych krajów regionu, w tym: 1) przerzucanie ciężaru dowodu na podatników (Węgry), 2) praktyka stosowania środków zabezpieczających w postaci zabezpieczającego podatku u źródła oraz jego natychmiastowa egzekucja z ruchomości i nieruchomości należących do podatnika (Rumunia).

3.1.5. Rola orzecznictwa sądowego i jego wpływ na prawo podatkowe

W państwach Europy Środkowo-Wschodniej - zgodnie z ich tradycją prawa stanowionego - orzecznictwo sądów w jakichkolwiek sprawach, w tym podatkowych, nie jest źródłem powszechnie obowiązującego prawa. Niemniej jednak, sprawozdawcy krajowi (z wyjątkiem Serbii) podkreślili praktyczne znaczenie orzecznictwa na płaszczyźnie wykładni prawa podatkowego, a także jego wpływ na proces legislacji przepisów prawa podatkowego.

Państwa Europy Środkowo-Wschodniej przyjmują dwa różne modele sądowej kontroli decyzji w sprawach podatkowych: 1) sądowa kontrola sprawowana przez sądy administracyjne (regionalne sądy administracyjne pierwszej instancji oraz Najwyższy Sąd Administracyjny - jako sąd drugiej instancji), oraz 2) sądowa kontrola sprawowana przez sądy powszechne. Pierwszy model występuje w Czechach, Polsce, Serbii i Słowacji. Drugi w Gruzji, Rumunii i na Węgrzech.

Zazwyczaj (z wyjątkiem Gruzji) skarga do sądu może zostać wniesiona dopiero po wyczerpaniu środków odwoławczych przewidzianych przez przepisy prawa proceduralnego. $\mathrm{W}$ niektórych państwach regionu (Czechy) przewiduje się procedurę obowiązkowego postępowania prejudycjalnego. Ponadto w wielu jurysdykcjach Europy Środkowo-Wschodniej dopuszcza się wniesienie skargi konstytucyjnej.

Sprawozdawcy krajowi z Rumunii i Serbii wskazali na następujące interesujące trendy. W Rumunii sądy są, co do zasady, oporne w kwestii pytań prejudycjalnych do TSUE. Z kolei w Serbii podatnicy nie mają nawyku szukania ochrony swoich interesów przed Serbskim Sądem Administracyjnym, głównie z następujących powodów: 1) brak wiary w możliwości i chęci sądów podważenia decyzji organów podatkowych, 2) długi czas trwania postępowań sądowych, 3) obawa przed potencjalną zemstą organów podatkowych w postaci częstszych i bardziej agresywnych kontroli podatkowych Ponadto wskazano na całe obszary prawa podatkowego w Serbii, w których brak jakiegokolwiek orzecznictwa (np. międzynarodowe prawo podatkowe). 
3.1.6. Rola Rzecznika Praw Obywatelskich lub odpowiedniego organu (jeśli istnieje) na polu ochrony praw podatnika

W jurysdykcjach kilku państw Europy Środkowo-Wschodniej występuje instytucja Rzecznika Praw Obywatelskich (Czechy, Gruzja, Polska, Rumunia, Słowacja), jednakże jego rolę na polu ochrony praw podatnika określono jako ograniczoną lub żadną. Wynika to z kilku powodów: w Czechach kompetencje Rzecznika Praw Obywatelskich nie obejmują podatków, zaś w Rumunii Rzecznik nie podjął do tej pory żadnych działań w kwestiach podatkowych.

Sprawozdawcy krajowi z Mołdawii, Polski, Serbii i Węgier jednomyślnie opowiedzieli się za pilną potrzebą powołania Rzecznika Praw Podatnika.

\subsection{Pozostałe zagadnienia}

3.2.1. Pozycja prawna i rola zawodowych organizacji doradców podatkowych

W większości państw Europy Środkowo-Wschodniej doradca podatkowy to samodzielny, ustawowo regulowany, wolny zawód zaufania publicznego (Czechy, Polska, Rumunia, Słowacja, Węgry). W niektórych państwach regionu funkcjonują profesjonalne (obowiązkowe) korporacje doradców podatkowych (izby bądź rady doradców podatkowych), działające jako zawodowe, niekomercyjne organizacje użyteczności publicznej. $\mathrm{Na}$ Węgrzech doradcy podatkowi zrzeszeni są w dwóch organizacjach tego rodzaju, żadna z nich nie ma statusu izby ani rady doradców podatkowych. W Rumunii Izba Doradców Podatkowych ma prawo udzielania licencji osobom zamierzającym wykonywać zawód doradcy podatkowego.

W Serbii doradztwo podatkowe uznawane jest za odrębny wolny zawód prawniczy, niemniej jednak brak jakichkolwiek regulacji określających pozycję prawną lub reprezentację doradców podatkowych. Taki sam stan prawny występuje w Mołdawii.

3.2.2. Administracja podatkowa i nowoczesne technologie (np. e-deklaracje)

Sprawozdawcy krajowi z Europy Środkowo-Wschodniej zaobserwowali technologiczny postęp w administracji podatkowej. Postęp ten obejmuje m.in.: elektroniczne przetwarzanie danych, okienka informacji podatkowych (Czechy), e-deklaracje podatkowe (obowiązkowe w przypadku 
osób prawnych podatników VAT i podatku akcyzowego; planowane zmiany zmierzają do objęcia tym obowiązkiem wszystkich podatników VAT i akcyzy), wstępnie wypełnione zeznanie podatkowe w podatku dochodowym od osób fizycznych - PFR PIT-37 (Polska), zapłata w formie elektronicznej niektórych podatków i opłat oraz wiele innych.

Wszystkie wymienione rozwiązania pojawiły się stosunkowo niedawno i zostały pozytywnie ocenione przez sprawozdawców krajowych. Odnotowano wzrost liczby podatników korzystających $\mathrm{z}$ elektronicznych form komunikowania się z organami podatkowymi. Mimo tego, w niektórych krajach regionu (Polska) osobisty kontakt podatnika z pracownikiem organu podatkowego nadal pozostaje najpopularniejszą formą komunikowania się z organami podatkowymi. W Rumunii pewne czynności związane z rejestracją niektórych dokumentów nadal muszą być dokonane na papierze.

3.2.3. Nastawienie podatników do administracji podatkowej oraz administracji podatkowej do podatników (atmosfera)

Zdaniem sprawozdawców krajowych z państw Europy Środkowo-Wschodniej, administracja podatkowa w ich krajach nie jest, co do zasady, przyjazna podatnikom. Niemniej jednak wzajemne relacje między podatnikami a administracją podatkową uległy radykalnym przemianom w porównaniu z początkowym okresem transformacji. W Europie Środkowo-Wschodniej płacenie podatków nadal postrzegane jest w kategoriach zła koniecznego, nie zaś patriotycznego obowiązku. Ponadto proces poboru podatków jako całość uznaje się za zbyt dolegliwy i niezmiernie zbiurokratyzowany.

4. Międzynarodowe praWo PodatKowe W OKRESiE PRZEMIAN SYSTEMÓW PODATKOWYCH PAŃSTW EUROPY ŚRODKOWO-WSCHODNIEJ

- JEGO ZNACZENIE I PRZYSZłE WYZWANIA

4.1. Rola i znaczenie jednostronnych środków służących eliminacji podwójnego opodatkowania

Sprawozdawcy krajowi z państw Europy Środkowo-Wschodniej uznali, że jednostronne środki służące zapobieganiu podwójnego opodatkowania w sensie prawnym spełniają uzupełniającą rolę w ich wewnętrznych systemach prawnych. Niemniej jednak ich znaczenie określono jako ważne, zwłaszcza gdy brak innych mechanizmów eliminujących to zjawisko, np. bilateralnych umów podatkowych. 
Co do zasady, państwa Europy Środkowo-Wschodniej stosują metodę jednostronnego kredytu podatkowego. W Czechach eliminacja podwójnego opodatkowania za pomocą środków jednostronnych opiera się na metodzie odliczeń (podatki zapłacone za granicą przez podatników-rezydentów Czech - są uznawane za wydatki redukujące wielkość podstawy opodatkowania). Ponadto czescy sprawozdawcy krajowi podkreślili występowanie innych uregulowań spełniających podobne funkcje, wśród nich wymieniono m.in.: zwolnienia nierezydentów przebywających na terytorium Czech wyłącznie w celu odbycia nauki lub poddania się zabiegom medycznym.

Brak jednostronnych środków służących eliminacji podwójnego opodatkowania w sensie prawnym odnotowano w Rumunii, niemniej jednak pewne uregulowania podatku dochodowego od osób fizycznych uznano za ekwiwalentne mechanizmy. Zaliczono do nich: zwolnienie z opodatkowania niektórych rodzajów dochodów uzyskanych ze źródeł znajdujących się poza terytorium Rumunii. W związku z faktem, że Rumunia stosuje zasadę terytorialności, nie występują żadne ulgi adresowane do podatników nierezydentów.

Serbscy sprawozdawcy krajowi podkreślili ograniczone znaczenie jednostronnych środków służących eliminacji podwójnego opodatkowania w ich kraju, głównie ze względu na następujące okoliczności: stan serbskiej gospodarki oraz niewielką liczbę podatników-rezydentów Serbii osiągających dochody z zagranicznych źródeł.

4.2. Bilateralne środki zapobiegające podwójnemu opodatkowaniu. Rodzaje bilateralnych umów podatkowych

W okresie poprzedzającym transformację rola międzynarodowego prawa podatkowego we wszystkich państwach Europy Środkowo-Wschodniej oraz w Rosji była marginalna. Dawne państwa socjalistyczne (z wyjątkiem byłej Jugosławii) należące do Rady Wzajemnej Pomocy Gospodarczej (RWPG) zawarły dwa wielostronne traktaty: 1) Porozumienie z Miszkolca o unikaniu podwójnego opodatkowania dochodów i majątku osób (1977) oraz 2) porozumienie z Ułan Bator o unikaniu podwójnego opodatkowania dochodów i majątku osób prawnych (1978).

Sprawozdawcy krajowi z Europy Środkowo-Wschodniej zwrócili uwagę na to, iż w latach 70. i 80. XX w. zawarto wiele bilateralnych umów podatkowych z państwami Europy Zachodniej oraz państwami spoza bloku wschodniego. Zdziwienie może budzić fakt, że nieliczne z tych umów 
nadal obowiązują. Rozwiązania w nich zastosowane są oparte na pierwotnych wersjach Konwencji Modelowej OECD w sprawie podatku od dochodu i majątku (dalej: KM OECD). Aczkolwiek wiele z bilateralnych umów podatkowych $\mathrm{z}$ tego okresu $\mathrm{z}$ tzw. państwami rozwijającymi się zawiera unormowania inspirowane rekomendacjami Konwencji Modelowej ONZ w sprawie eliminacji podwójnego opodatkowania między państwami rozwiniętymi a rozwijającymi się (dalej: KM ONZ). Gruzja i Mołdawia rozpoczęły proces budowy sieci bilateralnych umów podatkowych od zera po uzyskaniu niepodległości.

Obok bilateralnych umów podatkowych w sprawie unikania podwójnego opodatkowania dochodu i majątku, niektóre państwa Europy Środkowo-Wschodniej (Czechy, Jugosławia, Polska, Słowacja, Węgry) zawarły także bilateralne umowy podatkowe w odniesieniu do podatku od spadków. Są one nieliczne i ich znaczenie jest ograniczone.

Współcześnie sieć bilateralnych umów podatkowych w państwach Europy Środkowo-Wschodniej jest imponująca. Czechy, Polska i Węgry mają największą liczbę bilateralnych umów podatkowych w odniesieniu do podatków od dochodu i majątku. Także liczna bilateralnych umów podatkowych zawartych przez Gruzję i Mołdowę oraz Serbię jest duża. Oznacza to, że umowy te są obecnie najważniejszym i najbardziej skutecznym środkiem służącym eliminacji podwójnego opodatkowania w sensie prawnym we wszystkich państwach regionu.

Obok bilateralnych umów podatkowych w odniesieniu do podatków od dochodu i majątku niektóre państwa środkowoeuropejskie zawarły kilka innych typów bilateralnych umów podatkowych. Sprawozdawcy krajowi z Czech i Polski podkreślili rosnącą liczbę bilateralnych umów o wymianie informacji w sprawach podatkowych z państwami i terytoriami określanymi jako „raje podatkowe”.

\subsection{Wielostronne umowy podatkowe w praktyce traktatowej}

Wielostronne umowy podatkowe występują rzadko praktyce traktatowej państw. Poza wspomnianymi już wielostronnymi porozumieniami zawartymi w Miszkolcu i Ułan Bator w ramach RWPG, państwa Europy Środkowo-Wschodniej nie są stronami żadnej wielostronnej umowy w sprawach zapobiegania unikaniu podwójnemu opodatkowaniu dochodu i majątku.

Czechy, Polska, Rumunia i Słowacja, o czym była mowa, są stronami wielostronnej konwencji w sprawie eliminacji podwójnego opodatkowania 
w sensie ekonomicznym dochodów przedsiębiorstw powiązanych (Konwencja Arbitrażowa). Ponadto Polska zawarła trzy wielostronne traktaty w odniesieniu do opodatkowania pojazdów drogowych.

Wszystkie państwa Europy Środkowo-Wschodniej reprezentowane na konferencji są stroną Wielostronnej Konwencji o Pomocy Administracyjnej w Sprawach Podatkowych.

\subsection{Rola KM OECD i KM ONZ w praktyce traktatowej}

Czechy, Polska, Słowacja i Węgry są państwami członkowskimi OECD, zatem, co do zasady, praktyka traktatowa tych państw opiera się na rekomendacjach KM OECD. Niemniej jednak pewne zalecenia KM ONZ występują często $\mathrm{w}$ bilateralnych umowach podatkowych zawartych przez niektóre z tych państw (Polska). Sprawozdawczynie krajowe z Polski wskazały m.in. na normy rozdzielające roszczenia podatkowe między umawiające się państwa w odniesieniu do należności licencyjnych, które niemalże w 100\% recypują postanowienia KM ONZ do polskiej praktyki traktatowej.

Żadne $\mathrm{z}$ państw środkowoeuropejskich reprezentowanych na konferencji nie posiada własnej, krajowej konwencji modelowej. Podobnie Gruzja i Mołdawia. „Krajowa” konwencja modelowa funkcjonuje w Serbii w postaci nieoficjalnego dokumentu wykorzystywanego przez serbskich przedstawicieli w trakcie negocjacji bilateralnych umów podatkowych. Serbska konwencja modelowa stanowi sui generis kombinację rekomendacji zawartych w KM OECD i KM ONZ. Serbscy sprawozdawcy krajowi podkreślili dominujący wpływ Komentarza do KM OECD w procesie interpretacji bilateralnych umów podatkowych. Podobny trend odnotowano także w Gruzji i Mołdawii.

\subsection{Instrumenty międzynarodowej współpracy w sprawach podatkowych}

Międzynarodowa współpraca w sprawach podatkowych uskuteczniana jest w oparciu albo o regulacje prawa wewnętrznego, albo umowy międzynarodowe (dwustronne, wielostronne) i obejmuje w szczególności: procedurę wzajemnego porozumiewania się, wymianę informacji w sprawach podatkowych oraz pomoc w poborze podatków. Państwa Europy Środkowo-Wschodniej należące do Unii Europejskiej transponowały do prawa wewnętrznego unormowania następujących dyrektyw: 1) dyrektywę Rady 2011/16/UE z 15 lutego 2011 o współpracy administracyjnej 
w sprawach podatkowych oraz 2) dyrektywę Rady 2010/24/UE z 16 marca 2010 r. w sprawie wzajemnej pomocy w egzekucji roszczeń podatkowych, opłat i innych należności publiczno-prawnych.

Brak regulacji prawa krajowego w zakresie procedury wzajemnego porozumiewania się został wskazany przez sprawozdawczynie krajowe z Polski. Procedura ta opiera się na uregulowaniach bilateralnych umów podatkowych zawartych przez Polskę. Odmiennie, krajowe przepisy regulujące procedurę wzajemnego porozumiewania się funkcjonują $\mathrm{w}$ prawie wewnętrznym Węgier.

4.6. Środki zapobiegające unikaniu opodatkowania - międzynarodowe aspekty

Prawo wewnętrzne państw Europy Środkowo-Wschodniej czyni rozróżnienie między unikaniem opodatkowania a uchylaniem się od opodatkowania. Oba zjawiska zostały po raz pierwszy dostrzeżone we wczesnych stadiach transformacji. Formy unikania opodatkowania (włączając fizyczną ucieczkę przed opodatkowaniem) wymienione przez sprawozdawców krajowych z regionu obejmują m.in.: 1) transfer pasywów do spółek utworzonych $\mathrm{w}$ rajach podatkowych, 2) transakcje z podmiotami zarejestrowanymi w rajach podatkowych, 3) fikcyjne umowy dotyczące usług niematerialnych, 4) przerzucanie dochodów pomiędzy przedsiębiorstwami powiązanymi (ceny transferowe), 5) nadmierne zadłużanie się spółek kapitałowych u swoich udziałowców (akcjonariuszy) - niedostateczna kapitalizacja, 6) wykorzystywanie hybrydowych instrumentów finansowania spółek zależnych, oraz wiele innych sztucznych konstrukcji prawnych, których wyłącznym celem jest minimalizacja obciążeń podatkowych.

Do instrumentów prawnych wprowadzonych w celu zapobiegania unikaniu opodatkowania zaliczono: 1) klauzulę generalną przeciwko unikaniu opodatkowania (ang. general anti-avoidance rule, GAAR), 2) klauzule szczególne eliminujące poszczególne praktyki tego rodzaju (ang. special anti-avoidance rules, SAARs). Klauzula ogólna przeciwko unikaniu opodatkowania o charakterze normatywnym lub doktryna orzecznicza oparta o koncepcję przewagi treści stosunku-prawnego lub prawa nad jej cywilno-prawną formą występuje we wszystkich państwach Europy Środkowo-Wschodniej z wyjątkiem Czech i Polski. Sprawozdawcy krajowi z Polski i Węgier podnieśli konstytucyjne ograniczenia przemawiające za wprowadzeniem takiej klauzuli do wewnętrznego prawa podatkowego. 
Klauzule szczególne przeciwko unikaniu opodatkowania funkcjonujące w jurysdykcjach środkowo i wschodnioeuropejskich obejmują: przepisy w zakresie cen transferowych, przepisy o niedostatecznej kapitalizacji (z wyjątkiem Gruzji i Mołdawii), przepisy w zakresie zagranicznych spółek kontrolowanych, CFC rules (z wyjątkiem Gruzji, Mołdawii i Serbii), szczególnego rodzaju podatki u źródła nakładane na dywidendy, odsetki i należności licencyjne wypłacane spółkom z siedzibą w jurysdykcjach stosujących szkodliwą konkurencję podatkową (Czechy) oraz uregulowania w zakresie wymiany informacji w sprawach podatkowych. W żadnym z państw Europy Środkowo-Wschodniej reprezentowanych na konferencji nie występuje tzw. podatek od wyjścia (ang. exit tax).

Uchylanie się od opodatkowania, w odróżnieniu od unikania opodatkowania, ma charakter przestępczy. Sprawozdawcy krajowi z Europy Środkowo-Wschodniej wskazali, że praktyki tego rodzaju dotykają w szczególności podatek dochodowy oraz VAT. W przypadku podatków dochodowych uchylanie się od opodatkowania polega m.in. na nieujawnianiu lub zaniżaniu dochodów do opodatkowania, zaś w VAT do praktyk tych należą: 1) oszustwa związane $\mathrm{z}$ tzw. znikającym kontrahentem, zwłaszcza przy wewnątrzwspólnotowym nabyciu towarów, 2) karuzele podatkowe, 3) niedeklarowanie nabycia towarów w państwie przeznaczenia, 4) pozorowanie wewnątrzwspólnotowego charakteru transakcji oraz 5) dokonywanie odliczenia podatku naliczonego na podstawie fałszywych faktur VAT i inne.

Uchylanie się od opodatkowania nosi znamiona przestępstwa lub wykroczenia karnoskarbowego. Zwalczanie tego zjawiska odbywa się zatem za pomocą norm prawa karnego (karnoskarbowego), nie podatkowego, choć administracja podatkowa czynnie uczestniczy w procedurach przygotowawczych w sprawach karnych.

4.7. Wpływ Planu BEPS na prawo wewnętrzne państw Europy Środkowo-Wschodniej

Ogólne nastawienie państw Europy Środkowo-Wschodniej do Planu BEPS (ang. OECD/G20 Base Erosion and Profit Shifting Action Plan, BEPS) zostało pozytywnie ocenione. Sprawozdawcy krajowi z Czech i Polski podkreślili, że założenia Planu BEPS są często przedmiotem publicznej debaty, zaś zmiany wewnętrznego prawa podatkowego w tych państwach, wynikające z implementacji założeń Planu BEPS, wkrótce staną się faktem 
(np. wprowadzenie klauzuli ogólnej przeciwko unikaniu opodatkowania w Czechach i Polsce) lub już zostały wdrożone (np. przepisy o zagranicznych spółkach kontrolowanych, CFC rules w Polsce). Brak reakcji na Plan BEPS wskazano jedynie w węgierskim raporcie krajowym. Z kolei sprawozdawcy krajowi z Serbii wyrazili pogląd, że „założenia Planu BEPS nie dotarły jeszcze do granic Serbii”.

Sprawozdawcy krajowi z Czech i Węgier zwrócili uwagę na pewne zagrożenia wynikające $\mathrm{z}$ wdrożenia Planu BEPS. W Czechach podkreślono obawy związane z reakcją sądów na stosowanie tak skomplikowanych i złożonych regulacji. Zdaniem węgierskich sprawozdawców krajowych implementacja Planu BEPS może negatywnie wpłynąć na politykę podatkową tego kraju, który nadal jest państwem importującym głównie kapitał i nowoczesne technologie. Ich zdaniem, w interesie Węgier winno w pierwszej kolejności leżeć tworzenie rozwiązań prawnopodatkowych przyciągających, a nie odstraszających zagranicznych inwestorów.

5. WNIOSKI KOŃCOWE

Proces transformacji systemów podatkowych państw Europy Środkowej i Wschodniej wykazuje wiele cech wspólnych. Zaliczyć do nich należy przede wszystkim wyodrębnienie się prawa podatkowego jako odrębnej od prawa finansowego gałęzi prawa, wykształcenie się wyraźnego podziału na podatki stanowiące dochody budżetu państwa (federacji) i budżetów lokalnych, ucywilizowanie procesów legislacji podatkowej i oparcie ich o zasadę nullum tributuum sine lege, a także wpływ sądownictwa na tworzenie i wykładnię prawa podatkowego.

Jedną z cech wspólnych systemów podatkowych państw Europy Środkowej i Wschodniej jest dominująca rola podatków pośrednich w systemie źródeł dochodów budżetu państwa (federacji) i marginalna rola podatków majątkowych. Znaczenie tych ostatnich mierzyć można jedynie w kategoriach ich roli w strukturze dochodów samorządów lokalnych. Jednocześnie sprawozdawcy krajowi z państw Europy Środkowej i Wschodniej zgodnie podkreślili społeczne znaczenie podatków bezpośrednich, w tym zwłaszcza pozafiskalne funkcje realizowane przy ich pomocy. We wszystkich systemach podatkowych państw Europy Środkowej i Wschodniej istnieją bowiem szczególne (preferencyjne) zasady opodatkowania dochodów z działalności gospodarczej, ulgi podatkowe związane z badaniami naukowymi o nowoczesnymi technologiami i inne zachęty podatkowe oraz 
uregulowania prawne uwzględniające osobistą sytuację podatnika, w tym jego status rodzinny.

Systemy podatkowe państw Europy Środkowej i Wschodniej, poza kwestiami związanymi ze strukturą organizacyjną administracji podatkowej oraz kontrolą sądową dezycji podatkowych, cechują daleko idące podobieństwa w zakresie znaczenia oraz rodzajów interpretacji podatkowych czy procesowych gwarancji praw podatnika, Podobna jest rola i wpływ orzecznictwa sądowego na prawo podatkowe.

Cechę wspólną systemów podatkowych państw Europu Środkowej i Wschodniej stanowi ponadto wpływ międzynarodowych organizacji i międzynarodowego (OECD, Unia Europejska) prawa podatkowego na kształt regulacji prawa krajowego. Sukcesem państw regionu jest rozbudowana sieć bilateralnych umów podatkowych, w tym umów o unikaniu podwójnego opodatkowania dochodu i majątku oraz zapobieganiu uchylaniu się od opodatkowania. Sprawozdawcy krajowi podkreślili oparcie praktyki traktatowej w ich państwach o Konwencję Modelową OECD w sprawie podatku od dochodu i majątku, wskazując jednocześnie na istotny wpływ Konwencji Modelowej ONZ w sprawie unikania podwójnego opodatkowania między państwami rozwiniętymi a rozwijającymi się na kształt pewnych rozwiązań $\mathrm{w}$ bilateralnych umowach podatkowych (m.in. opodatkowanie w państwie źródła należności licencyjnych). Podkreślono także rosnące znaczenie instrumentów służących międzynarodowej współpracy w sprawach podatkowych oraz środków zapobiegających unikaniu opodatkowania w skali międzynarodowej, w tym implementację Planu BEPS.

Summary. This report is the result of the international conference The Transformation of Tax Systems in the CEE and BRICS Countries - 25 years of experience and future challenges organized by the Centre of Tax Documentation and Studies in Lodz, in cooperation with the International Bureau of Fiscal Documentation (IBFD) in Amsterdam, Foundation of the Centre of Tax Documentation and Studies and the Polish Branch of International Fiscal Association (IFA). The conference was held on 9 and 10 October 2015 on the premises of the Faculty of Law and Administration of the University of Lodz.

The report deals with the general and specific legal and tax policy aspects of the transformation of tax systems in Central and Eastern European (CEE) countries in the years 1990-2015 in different areas of tax law: substantive, procedural and international. The future challenges for the tax laws in these countries are also covered.

The report focuses on not only purely legal aspects of the transformation of tax systems and the evaluation of the resulting legislation, but also on tax policy aspects and future challenges in these countries. Identifying experience of the CEE countries in the field of 
transformation of tax systems and contemporary and future challenges of these systems, is a necessary step in a quest for creating better tax legislation, more suited to the needs of taxpayers and tax administration in the modern economy. Among other things, the following issues are discussed: relations between constitutional and tax law, standards of tax legislative process, concepts and standards of national policies, the problem of tax resistance, importance and construction of different types of taxes, tax aspects of Research and Developments and other tax incentives, as well as types of available tax rulings and procedural guarantees of taxpayers' rights and their effectiveness. Moreover, the role and importance of unilateral, bilateral and multilateral measures against double taxation, including the impact of the OECD Model Convention on Income and Capital, UN Model Convention between Developed and Developing Countries and the OECD/G20 BEPS Action Plan are highlighted.

Keywords: transformation, tax system, CEE countries, tax policy 